\title{
Guided inquiry with sparkol videosribe in science learning: a study of students' scientific attitudes
}

\author{
Abdur Rasyid ${ }^{{ }^{*}}$, Mukarramah Mustari ${ }^{2}$, Yunia Nabila Aziziy ${ }^{3}$, Dede Salim Nahdi ${ }^{1}$ \\ ${ }^{1}$ Universitas Majalengka, Indonesia \\ ${ }^{2}$ UIN Raden Intan Lampung, Indonesia \\ ${ }^{1}$ IAIN Madura, Indonesia \\ *Coresponding Author: abdurrasyid87@unma.ac.id
}

\begin{abstract}
Scientific attitude is an important element in learning Natural Sciences (IPA) which must be instilled early on. However, many studies reveal that students in elementary schools still have a low scientific attitude so it takes some effort to improve it. Efforts that can be done include implementing a learning model and media that are thought to facilitate students in developing their scientific attitude, one of which is the Guided Inquiry model with Sparkol Videoscribe learning media. This research has the aim of improving students' scientific attitudes by applying the Guided Inquiry model assisted by Sparkol Videoscribe in science learning. The method used in this study is a quasi-experimental type of experimental research and the Nonequivalent control group design. The population in this study were all grade 5 students of elementary schools in Cigasong Sub-district, Majalengka with the sample being grade 5 students of SDN Cicenang 1, Majalengka of two classes. The results of the study illustrate that the scientific attitude of students who obtained the Guided Inquiry model assisted by Sparkol Videoscribe was better than students who obtained conventional learning. From these results, it can be concluded that the Guided Inquiry model assisted by Sparkol Videoscribe is effective in improving students' scientific attitudes.
\end{abstract}

\author{
ARTICLE HISTORY \\ Received 2022-12-15 \\ Accepted 2022-01-31 \\ KEYWORDS \\ Scientific Attitude \\ Guided Inquiry \\ Sparkol Videoscribe \\ Natural Science \\ Elementary School
}

\section{INTRODUCTION}

The level of development of each country is largely determined by the progress of science (Olasehinde \& Olatoye, 2014). Natural Sciences (IPA) is one of the disciplines that plays a very crucial role in encouraging the development of science. This is because every science learning carried out emphasizes experimental activities that can train and develop students in thinking, working and behaving better (Sreetanuka \& Thomas, 2012). One of the goals of learning science is to encourage students to have a positive attitude towards science and to have a positive impact on student learning (Stepanek, 2000). Therefore, every teacher should carry out science learning by using learning strategies and methods that facilitate students to grow their scientific attitude (Sukaesih, 2011).

Attitude is a general feeling either positive or negative about a person, object or problem (Jones \& Butts, 1983). Attitude is a person's belief about a certain object that gives rise to a tendency to take action against that object with a certain mechanism (Calhoun \& Acocella, 1990). Attitude is not 
behavior, but a tendency or predisposition of behavior. The scientific attitude is an attribute of someone who not only acts what they want outwardly but also understands why they do it (Rao, 2003). The scientific attitude in science has been taught from the beginning through the discovery of concepts (Astalini et al, 2019). Scientific Attitude is a state of mind that allows creative thinking about Nature and its phenomena, and engaging in scientific research on those phenomena (Arseculeratne, 2014). A scientist or academician needs to have a scientific attitude in solving various problems (Anwar, 2009). Scientific attitudes will appear in students when interacting with various newly encountered phenomena and from their experiences and insights (Tunisa et al, 2017). Scientific attitudes have a positive impact on students' character and can shape students' character for the better (Samatowa, 2011).

Given the importance of having a scientific attitude in children from an early age, the science learning carried out must be able to facilitate children to develop their scientific attitude. However, several studies reveal the fact that students' scientific attitudes are low, so efforts need to be made to improve them (Kusumawati, 2018; Wijayanto, Utomo, \& Haryono, 2017; Oktarian \& Blitar, 2019). The low scientific attitude is also experienced by most elementary school students in Cigasong District, Majalengka Regency. Based on observations and interviews with several teachers, it was found that students' interest and motivation in learning science were still low, they seemed less enthusiastic and tended to be passive when learning in class. Many students seemed to follow the lesson less and talked more with their friends when the teacher delivered the lesson. This condition indicates that the attitude of students' critical thinking skills, cooperation, curiosity, and accuracy is still low. In other words, these students do not yet have a scientific attitude. To improve students' scientific attitudes, several efforts can be made, including by applying learning strategies and media that can facilitate students to develop these attitudes. Teachers as facilitators and leaders of the learning process need to develop interesting and appropriate learning strategies and also provide learning media that make it easier for students to understand the material. One of the learning models that are thought to be appropriate in growing students' scientific attitudes is the guided inquiry model. The media that is suspected to be able to facilitate students' scientific attitude is the use of Sparkol Videoscribe.

The concept of inquiry-based learning has emerged several times as one of the educational philosophies of great educators throughout history (Vlassi \& Karaliota, 2013). Inquiry-based learning is learning that requires students to be active and involved in observing activities, formulating questions, and investigating sources of information to see what is known. (Arslan, 2014) so that it makes learning more meaningful (Suryani \& Sudargo, 2016). The application of the inquiry model in science learning has several times encouraged the achievement of student competencies (Zhang, 2016). Many important studies have been carried out on the inquiry approach, including that students learn better because they can build their own knowledge. The study was conducted to test these assumptions by comparing low and high learning outcomes in the classroom with inquiry learning and traditional learning (Huppert, Lomask, Lazarowitz, \& Lomask, 2010; Akkus, Gunel, \& Hand, 2007; Huppert et al., 2010; Geier et al., 2008; Liao \& She, 2009; Wilson, Taylor, Kowalski, \& Carlson, 2010);. In this study apply the Guided Inquiry model. In carrying out science learning with the Guided Inquiry model, it can have an effect on increasing learning motivation, thinking skills, and scientific attitudes (Lee, 2011; Kubicek, 2005). In its implementation, the Guided Inquiry Model provides various learning instructions provided by the teacher (Wenning \& Khan, 2011). The Guided Inquiry model can help students improve their scientific inquiry skills (Chang et al., 2011; Campbell, Abd-Hamid, \& Chapman, 2010);, serta memfasilitasi siswa dalam mengembangkan sikap ilmiahnya (Şimşek \& Kabapinar, 2010; Remziye Ergul et al., 2011; Ulva, Ibrohim, \& Sutopo, 2017). In addition, several research results have been carried out, including by Ulva 
et al. (2017), Dewi, Dantes, \& Sadia (2013), (Hendracipta, 2016), Maya, Murningsih, Masykuri, \& Mulyani (2016), dan Margiastuti, Parmin, \& Pamelasari (2016) reveal the fact that Guided Inquiry is successful in developing students' scientific attitude.

The Sparkol Videoscribe learning media is used on the basis that this media can present teaching materials in the form of interesting videos (Jannah, Harijanto, \& Yushardi, 2019). Media Sparkol Videoscribe is a web-based feature that provides various types of presentations in the form of videos (Munawarah, 2019). This media can display teaching materials through a combination of images, sound and design (Rahmawati et al, 2017; Kholidin et al, 2017; Pamungkas et al, 2018) so that it makes students more interested and enjoy learning activities in class (Dewi et al, 2019).

\section{METHODS}

The method used in this study is an experimental study with a quasi-experimental type. The research design used is the Noneequivalent control group design. In this research design, two groups were used as research samples, namely the experimental group and the control group. The experimental group is a group of students who carry out science learning using guided inquiry assisted by videoscribe and the control group is a group of students who carry out conventional science learning.

In this study, both groups were given a pre-test before being given treatment. In the design of this study, the treatment in the two groups was different. For the experimental group, students were treated by applying the Guided Inquiry model assisted by Sparkol videoscribe and in the control group, students were given conventional learning. After completing the treatment, both groups of students were given a post-test.

In this study, the population used were all 5th grade elementary school students in Cigasong District, Majalengka Regency. The author took a sample of two classes of students at SDN Cicenang 1, Cigasong District, Majalengka Regency. The sample is VC class with 22 people as the experimental group and 22 people in VD as the control group. The instruments used in this research are questionnaires and observations to see the scientific attitude of students. The data obtained were then analyzed quantitatively using independent samples t-test.

\section{RESULTS AND DISCUSSION}

In measuring students' scientific attitude, the author uses a questionnaire that has been declared valid and reliable based on the results of the instrument trial. Questionnaires were given before and after treatment. Descriptive statistics on the results of measuring students' scientific attitudes before and after being given treatment to the two groups of students can be seen in table 1 .

Table 1. Descriptive Statistics of the Results Of Measuring Students' Scientific Attitudes

\begin{tabular}{lcccc}
\hline \multicolumn{1}{c}{ Group } & Test & N & Mean & Std. Dev. \\
\hline Experiment & Pretest & 22 & 68,32 & 1,716 \\
& Posttest & 22 & 80,41 & 1,530 \\
Control & Pretest & 22 & 71,23 & 2,642 \\
& Posttest & 22 & 73,68 & 2,594 \\
\hline
\end{tabular}

Table 1 shows that the number $(\mathrm{N})$ of students who took the test in the experimental group was 22 students. The mean pre-test data is 68.32 with a standard deviation of 1.716 and the mean post-test 
data is 80.41 with a standard deviation of 1.530 . In the control class, the number $(\mathrm{N})$ of students was 22 people. the mean pre-test data is 71.23 and the standard deviation is 2.642 and the mean post-test data is 73.68 with a standard deviation of 2.642 .

To see the effect of each treatment, namely the Guided Inquiry model assisted by Sparkol videoscribe and conventional science learning, on students' scientific attitudes, an analysis of the difference between the two averages of the pretest and posttest data was carried out in both groups of students through the Paired Sample T-Test. The pretest and posttest data analyzed have been declared to be normally distributed and homogeneous (same) through normality and homogeneity testing. The results of the calculation of the Paired Sample T-Test in both classes are presented in table 2.

Table 2. The results of the calculation of the Paired Sample T-Test Data Pretest and Posttest

\begin{tabular}{lccc}
\hline Group & $\mathrm{t}$ & $\mathrm{df}$ & Sig. \\
\hline Experiment & $-8,588$ & 21 & 0,000 \\
Control & $-2,083$ & 21 & 0,050 \\
\hline
\end{tabular}

From table 2, the results of the calculation of the Paired Sample T-Test on the pretest and posttest data of the experimental group with sig. which is 0.000 less than $=0.05$, it means that there is a significant difference between students' scientific attitudes before and after using the Guiden Inquiry model assisted by Sparkol Videoscribe. As for the control group, the results of the Paired Sample T-Test calculation obtained the value of Sig. i.e. 0.050 is equal to $=0.05$, it can be interpreted that the scientific attitude of students before and after conventional science learning is applied is the same or there is no difference. So from the results of the Paired Sample T-Test calculation above, it can be concluded that the Guiden Inquiry model assisted by Sparkol Videoscribe can improve students' scientific attitudes compared to conventional learning. However, to provide more confidence, the authors continued the analysis by comparing the posttest data in the two research sample groups through the calculation of the Independent Sample T-Test. The posttest data of the two samples had previously been declared homogeneous based on the homogeneity test. The results of the calculation of the Independent Sample T-Test posttest for the experimental and control groups are presented in table 3.

From table 3, the results of the calculation of the Independent Sample T-Test posttest data for the two sample groups are obtained. From the data in table 4, it is known that the value of sig. of 0.031 less than $=0.05$, then there is a significant difference in the scientific attitude of students who carry out science learning with the Guide Inquiry model assisted by Sparkol Videoscribe with students who carry out conventional science learning.

Table 3. Calculation results of Independent Sample T-Test

\begin{tabular}{lccc}
\hline Data & $\mathrm{t}$ & $\mathrm{df}$ & Sig. \\
\hline posttest & 2,234 & 42 & 0,031 \\
\hline
\end{tabular}

Based on the results of the descriptive statistical calculations in table 1, the average posttest of the experimental class is greater than the average of the posttest of the control class. From these results, it can be concluded that the scientific attitude of students carrying out science learning with the Guide Inquiry model assisted by Sparkol Videoscribe is better than the scientific attitude of students who carry out conventional science learning. 
The difference in students' scientific attitudes between the two groups of students showed that the Guide Inquiry model assisted by Sparkol Videoscribe was effective in improving students' scientific attitudes. The results of this study can be understood because the guided inquiry learning process is student-centered and makes students more flexible to be active in science learning activities in class. The Guide Inquiry Model is carried out with the teacher having a role as a facilitator which aims to encourage students to build their own knowledge. During learning students are guided by the teacher to be able to formulate problems to make conclusions. In addition, in Guide Inquiry students learn in groups to be able to solve problems that are often found in their lives. The process of finding a solution to a given problem is a stage of the scientific method. This process can develop a scientific attitude in students. In addition, the existence of learning videos in the form of Sparkol Videoscribe media as a presentation of learning information makes it easy for students to understand and explore the problems given so that students become easy to solve problems.

\section{CONCLUSION}

The results of this study illustrate that the scientific attitude of students who received the Guide Inquiry model with the help of Sparkol Videoscribe was better than the group of students who carried out conventional science learning. From these results it can be concluded that the Guide Inquiry model assisted by Sparkol Videoscribe is effective in improving students' scientific attitudes.

\section{REFERENCES}

Akkus, R., Gunel, M., \& Hand, B. (2007). Comparing an Inquiry-based approach known as the Science Writing Heuristic to traditional science teaching practices: Are there differences? International Journal of Science Education, 29(14), 1745-1765. https://doi.org/10.1080/09500690601075629

Anwar, H. (2009). Penilaian Sikap Ilmiah Dalam Pembelajaran Sains. Jurnalpelangi limu, 2(5), 103-113. Retrieved from http://ejurnal.ung.ac.id/index.php/JPI/article/view/593/544

Arseculeratne, S. (2014). The Scientific Attitude (The Scientific Temper) in Eastern and Western societies. Anuradhapura Medical Journal, 8(1), 22. https://doi.org/10.4038/amj.v8i1.6757

Arslan, A. (2014). Transition between Open and Guided Inquiry Instruction. Procedia - Social and Behavioral Sciences, 141, 407-412. https://doi.org/10.1016/j.sbspro.2014.05.071

Astalini, A., Kurniawan, D. A., Kurniawan, N., \& Anggraini, L. (2019). Evaluation of Student's Attitude Toward Science in Indonesia. Open Journal for Educational Research, 3(2), 39-52. https://doi.org/10.32591/coas.ojer.0302.01039h

Calhoun, J. F., \& Acocella, J. R. (1990). Psychology of adjustment and human relationships. Psychology of Adjustment and Human Relationships.

Campbell, T., Abd-Hamid, N. H., \& Chapman, H. (2010). Development of instruments to assess teacher and student perceptions of inquiry experiences in science classrooms. Journal of Science Teacher Education, 21(1), 13-30. https://doi.org/10.1007/s10972-009-9151-x

Chang, H. P., Chen, C. C., Guo, G. J., Cheng, Y. J., Lin, C. Y., \& Jen, T. H. (2011). The development of a competence scale for learning science: Inquiry and communication. International Journal of Science and Mathematics Education, 9(5), 1213-1233. https://doi.org/10.1007/s10763-010-9256$\mathrm{x}$

Dewi, C. S., Suprapto, P. K., \& Badriah, L. (2019). Peranan Media Sparkol Videoscribe Terhadap Hasil Belajar Kognitif Siswa Lintas Minat Biologi. JPBIO (Jurnal Pendidikan Biologi), 4(2), 93-100. https://doi.org/10.31932/jpbio.v4i2.456 
Dewi, N. L., Dantes, N., \& Sadia, I. W. (2013). Pengaruh Model Pembelajaran Inkuiri Terbimbing Terhadap Aktivitas, Motivasi Dan Hasil Belajar. E-Journal Program Pascasarjana Universitas Pendidikan Ganesha, 3(1), 41-47.

Geier, R., Blumenfeld, P. C., Marx, R. W., Krajcik, J. S., Fishman, B., Soloway, E., \& Clay-Chambers, J. (2008). Standardized test outcomes for students engaged in inquiry-based science curricula in the context of urban reform. Journal of Research in Science Teaching, 45(8), 922-939. https://doi.org/10.1002/tea.20248

Hendracipta, N. (2016). Menumbuhkan Sikap Ilmiah Siswa Sekolah Dasar Melalui Pembelajaran IPA Berbasis Inkuiri. Jurnal Pendidikan Sekolah Dasar, 2(1), 109-116. https://doi.org/10.1017/CBO9781107415324.004

Huppert, J., Lomask, S. M., Lazarowitz, R., \& Lomask, S. M. (2010). International Journal of Computer simulations in the high school: Students 'cognitive stages, science process skills and academic achievement in microbiology. (May 2013), 37-41.

Jannah, M., Harijanto, A., \& Yushardi. (2019). Aplikasi Media Pembelajaran Fisika Berbasis Sparkol. Jurnal Pembelajaran Fisika, 8(2), 65-72.

Jones, B., \& Butts, B. (1983). Development of a set of scales to measure selected scientific attitudes. Research in Science Education, 13(1), 133-140. https://doi.org/10.1007/BF02356700

Kholidin, Hudaidah, \& Safitri, S. (2017). Pengembangan Media Pembelajaran Menggunakan Program Video Scribe Sparkol Pada Mata Pelajaran Sejarah Kelas XI di Sekolah Menengah Atas. Criksetra: Jurnal Pendidikan Sejarah, 6(2).

Kubicek, J. P. (2005). Inquiry-based learning, the nature of science, and computer technology: New possibilities in science education. Canadian Journal of Learning and Technology, 31(1). https://doi.org/10.21432/T29C77

Kusumawati, Y. (2018). Upaya Meningkatkan Keterampilan Proses dan Sikap IImiah Melalui Penerapan Metode Eksperimen. Jurnal Pendidikan Guru Sekolah Dasar, 7(19), 1865-1876.

Lee, V. S. (2011). The Power of Inquiry as a Way of Learning. Innovative Higher Education, 36(3), 149-160. https://doi.org/10.1007/s10755-010-9166-4

Liao, Y. W., \& She, H. C. (2009). Enhancing eight grade students' scientific conceptual change and scientific reasoning through a web-based learning program. Educational Technology and Society, 12(4), 228-240.

Margiastuti, S. N., Parmin, \& Pamelasari, S. D. (2016). Penerapan Model Guided Inquiry Terhadap Sikap Ilmiah Dan Pemahaman Konsep Siswa Pada Tema Ekosistem. Unnes Science Education Journal, 5(2), $1253^{-}$1260. https://doi.org/http://dx.doi.org/10.15294/usej.v3i2.3349

Maya, I., Murningsih, T., Masykuri, M., \& Mulyani, B. (2016). Penerapan Model Pembelajaran Inkuiri Terbimbing untuk Meningkatkan Sikap Ilmiah dan Prestasi Belajar Kimia Siswa Implementation of Guided Inquiry Model to Improve Behaviour Scientific and Student's Chemistry Learning Achievement. 2(2), 177-189.

Munawarah, R. Al. (2019). Sparkol videoscribe sebagai media pembelajaran. Jurnal Inspiratif Pendidikan, $8(2), 430-437$.

Oktarian, N. (2019). Meningkatkan Sikap Ilmiah Siswa Dengan Model Project Based Learning ( PBL ) Pada Kelas IX SMP Ar-Raudlah Jember. Jurnal Pembelajaran Sains, 3, 7-13.

Olasehinde, K. J., \& Olatoye, R. A. (2014). Scientific Attitude, Attitude to Science and Science Achievement of Senior Secondary School Students in Katsina State, Nigeria. Journal of Educational and Social Research, 4(1), 445-452. https://doi.org/10.5901/jesr.2014.v4n1p445 
Pamungkas, A. S., Ihsanudin, I., Novaliyosi, N., \& Yandari, I. A. V. (2018). Video Pembelajaran Berbasis Sparkol Videoscribe: Inovasi Pada Perkuliahan Sejarah Matematika. Prima: Jurnal Pendidikan Matematika, 2(2), 127. https://doi.org/10.31000/prima.v2i2.705

Rahmawati, F., Soegimin, \& Kardi, S. (2017). Pengembangan Perangkat Pembelajaran Fisika Model Inkuiri Terbimbing Berbantuan Videoscribe Pada Materi Kalor Untuk Meningkatkan Hasil Belajar Siswa Sman 1 Kedungwaru. JPPS (Jurnal Penelitian Pendidikan Sains), 5(2), 1039. https://doi.org/10.26740/jpps.v5n2.p1039-1047

Rao, D. B. (2003). Scientific Attitude Vis-A-Vis Scientific Aptitude. New Delhi: Discovery Publishing House.

Remziye Ergul, Simsekli, Y., Calis, S., Ozdilek, Z., Gocmencelebi, S., \& Sanli, M. (2011). The Effects Of Inquiry-Based Science Teaching On Elementary School Students' Science Process Skills And Science Attitudes. Bulgarian Journal of Science and Education Policy (BJSEP), 5(1), 48-69.

Samatowa, U. (2011). Pembelajaran IPA di Sekolah Dasar. Jakarta: Indeks.

Şimşek, P., \& Kabapinar, F. (2010). The effects of inquiry-based learning on elementary students' conceptual understanding of matter, scientific process skills and science attitudes. Procedia Social and Behavioral Sciences, 2(2), 1190-1194. https://doi.org/10.1016/j.sbspro.2010.03.170

Sreetanuka, N., \& Thomas, D. S. (2012). Enhancing Science Process Skills and Scientific Attitude and Analysing their Interactions.:- An Intervention through Inquiry Learning Approach. International Journal Of Scientific Research, 1(1), 37-42. https://doi.org/10.36106/ijsr

Stepanek, J. (2000). Mathematics and science classrooms: Building a community of learners. Retrieved from www.nwrel.org/msec/

Sukaesih, S. (2011). Analisis Sikap IImiah Dan Tanggapan Mahasiswa Terhadap Penerapan Model Pembelajaran Berbasis Praktikum. Jurnal Penelitian Pendidikan, 28(1), 77-85. https://doi.org/10.15294/jpp.v28i1.5628

Suryani, D. I., \& Sudargo, F. (2016). Pengaruh Model Pembelajaran Open Inquiry Dan Guided Inquiry Terhadap Sikap Ilmiah Siswa Smp Pada Tema Suhu Dan Perubahan. Edusains, 7(2), 127-134. https://doi.org/10.15408/es.v7i2.1628

Tunisa, F. R., Kosasih, \& Hamdu, G. (2017). Pengaruh Model Pembelajaran Latihan Penelitian terhadap Sikap Ilmiah siswa di Sekolah Dasar. Jurnal Ilmiah Pendidikan Guru Sekolah Dasar, 4(2), 149-157.

Ulva, V., Ibrohim, \& Sutopo. (2017). Mengembangkan Sikap Ilmiah Siswa SMP Melalui Pembelajaran Inkuiri Terbimbing pada Materi Ekosistem. Jurnal Pendidikan: Teori, Penelitian, Dan Pengembangan, 2(5), 622-626.

Vlassi, M., \& Karaliota, A. (2013). The Comparison between Guided Inquiry and Traditional Teaching Method. A Case Study for the Teaching of the Structure of Matter to 8th Grade Greek Students. Procedia - Social and Behavioral Sciences, 93, 494-497. https://doi.org/10.1016/j.sbspro.2013.09.226

Wenning, C. J., \& Khan, M. A. (2011). Levels of Inquiry Model of Science Teaching: Learning sequences to lesson plans. Journal of Physics Teacher Education Online, 6(2), 17-20.

Wijayanto, H., Utomo, S., \& Haryono, H. (2017). Upaya Peningkatan Sikap Ilmiah Dan Prestasi Belajar Siswa Melalui Penerapan Project Based Learning (PjBL) Dilengkapi Media Webquest Pada Pembelajaran Kimia Materi Sistem Koloid Kelas XI IPA 2 SMAN Gondangrejo Tahun Pelajaran 2015/2016. Jurnal Pendidikan Kimia, 6(1), 39-45.

Wilson, C. D., Taylor, J. A., Kowalski, S. M., \& Carlson, J. (2010). The relative effects and equity of inquirybased and commonplace science teaching on students' knowledge, reasoning, and 
Rasyid et al.

argumentation. Journal of Research in Science Teaching, 47(3), 276-301. https://doi.org/10.1002/tea.20329

Zhang, L. (2016). Is Inquiry-Based Science Teaching Worth the Effort?: Some Thoughts Worth Considering. Science and Education, 25(7-8), 897-915. https://doi.org/10.1007/s11191-0169856-0 